\title{
CHRONIC PAIN AND ANALGESIC USE IN HOSPITALIZED ELDERLY
}

\author{
DOR CRÔNICA E USO DE ANALGÉSICO EM IDOSOS HOPITALIZADOS
}

\section{Karoline Faria de OLIVEIRA ${ }^{1}$; Mariana Pereira CARVALHO² ; Ariane Mendonça NEVES $^{3}$; Jordânia Lumênia TAVARES ${ }^{4}$; Rejane Cussi Assunção LEMOS ${ }^{5}$; Alisson Fernandes BOLINA ${ }^{6}$; Luana Foroni ANDRADE ${ }^{7}$; Elizabeth BARICHELLO ${ }^{8}$; Rosalina Aparecida Partezani RODRIGUES ${ }^{9}$ Maria Helena BARBOSA ${ }^{10}$}

1. Nurse of the Health Sciences Institute - ICS, Federal University of Triângulo Mineiro - UFTM; PhD in Health Care at the UFTM; 2. Nurse from the UFTM; 3. Nurse at the UFTM Clinical Hospital; 4. Nurse. Master in Health Care from the UFTM; 5. Adjunct Professor of the ICS/ FTM. PhD in Health Care at the UFTM; 6. PhD in Postgraduate Program in Fundamental Nursing at theRibeirão Preto

College of Nursing; 7. PhD student in Health Care at the UFTM; Professor at the Federal University of Sergipe; 8. Associate Professor of the ICS/UFTM. PhD in Nursing at the Ribeirão Preto College of Nursing; 9. Full Professor at the University of São Paulo. PhD in Nursing from the University of São Paulo; 10. Associate Professor of the ICS/UFTM. PhD in Adult Health Nursing from the University of São Paulo. mhelena331@ @otmail.com

\begin{abstract}
To evaluate the chronic pain and analgesic use in elderly patients admitted to a teaching hospital. Cross-sectional, observational, non-experimental study with 100 elderly. Instruments for collection of demographic and health data, the Mc Gill evaluation scale and intensity of pain were used. The mean age was 71.1 years (SD + 7.4) and females prevailed in the sample (52\%); $78 \%$ of the respondents reported severe pain and $68 \%$ reported using painkillers. Pain was characterized as sensitive and stabbing (44\%), choking (39\%), unbearable (40\%) and nauseating (49\%). The findings of this study indicate a high chronic pain index and point to the need to create multidisciplinary programs of interventions focused on the evaluation and treatment of this symptom among hospitalized elderly.
\end{abstract}

KEYWORDS: Aged. Chronic Pain. Hospitalization. Aging. Quality of life. Pain Management.

\section{INTRODUCTION}

Elderly individuals require attention from hospital health professionals regarding the changes brought about by the senescence process. This process requires constant evaluation of the health team and control of vital signs, including the fifth sign which is pain. Pain can be characterized according to medical diagnosis or other conditions presented by the elderly. According to the International Association for the Study of Pain, chronic pain can be defined as an unpleasant feeling or emotional experience associated with actual or potential tissue damage, or described in terms of such damage. In the elderly, chronic pain is a common complaint and is a major cause of need for health care (DELLAROZA et al., 2013; MALEC; SHEGA, 2015), including hospital assistance.

Although important, hospitalization may eventually pose a high risk to health, especially for the elderly (MARQUES et al., 2014). In fact, hospitalization for several health conditions may increase the risk of adverse health outcomes (BODILSEN et al., 2016), with pain being an independent predictor of mortality in hospitalized elderly (HOFMAN et al., 2016). Furthermore, there are other side effects related to chronic pain in the elderly such as functional dependence, falls and depression (ABDULLA et al., 2013;
EGGERMONT et al., 2014; PATEL et al., 2014). Despite these serious consequences, a devaluation of this symptom by associating it with the senescence process has been observed among health professionals (BARBOSA et al., 2014).

Lack of adequate management and control of chronic pain in the elderly has been identified specifically in the hospital context (ABDULLA et al., 2013). This fact indicates the need to investigate and rethink the clinical guidelines of care for chronic pain in hospitalized elderly with a view to ensuring quality care and reducing hospitalization time. This contributes to the development of management protocols and provides benefits to health service managers, with subsidies for the creation of policies and programs.

In review of the literature, it was found that the majority of studies on the theme assesses pain in elderly community (DELLAROZA et al., 2013; EGGERMONT et al., 2014; PATEL et al., 2014) and in hospitalized individuals with specific clinical conditions (BHATTARAI; HICKMAN; PHILLIPS, 2016). Given these facts, the present study aimed to evaluate chronic pain according to intensity and sensory-affective-cognitive aspects, and describe the use of analgesics in elderly patients admitted to a teaching hospital. 


\section{MATERIAL AND METHODS}

\section{Characterization Study and Ethical Aspects}

This is a descriptive, cross-sectional, observational study in a public teaching hospital located in the city of Uberaba, at $494 \mathrm{~km}$ from the capital of Minas Gerais, Belo Horizonte, in southeastern Brazil. The hospital is a large institution and provides medical and surgical assistance to diseases of high complexity. The Ethics Committee for Research Involving Human Beings of the Federal University of Triangulo Mineiro approved the study under CEP/UFTM Opinion $n^{\circ}$ 1985/2011. The Foundation for Research Support of the State of Minas Gerais (FAPEMIG) and the National Council for Scientific and Technological Development (CNPq) supported this study.

\section{Sample and setting}

The unsystematic sample consisted of participants were found in medical units, in the
OLIVEIRA, K. F. et al.

surgical, neurology and orthopedics clinics. One hundred elderly people who met the inclusion criteria were interviewed. The inclusion criteria were age of 60 years and over; history of chronic pain (six months or more); and ability to verbally communicate. Elderly people who had serious medical conditions or any verbal or cognitive impairment that could prevent them from answering the survey questions (Figure 1). All the participants were included in the study after signing the Informed Consent Form.

\section{Data collection}

From November 2011 to March 2012, two researchers collected the data during day hours (between 08 and 18 hours) not to interfere with the sleep and rest of the elderly. Data were collected through interviews with aid of an instrument covering socio-demographic and health information (including self-reported data on the use of analgesics), a semiotic analysis of chronic pain, and two instruments for the assessment of chronic pain.

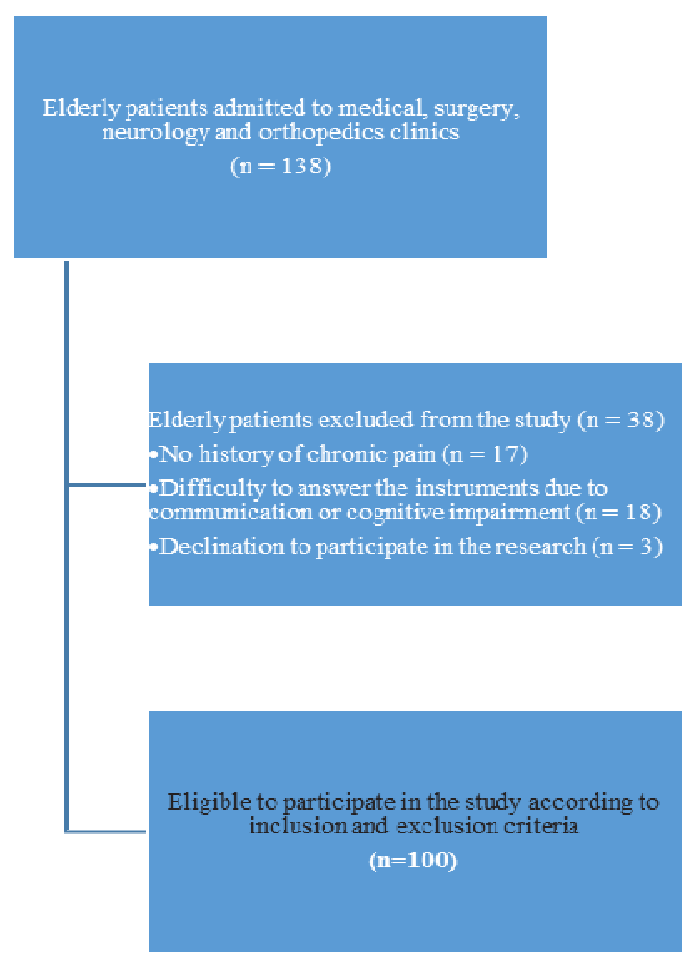

Figure 1. Diagram of eligibility of the population to participate in the research.

\section{Instruments}

To measure the semiologic characteristics of chronic pain, the authors developed an instrument that included aspects related to sociodemographic characteristics, use of painkillers in the home, types of painkillers and prescriptions, and self-reported morbidities.
The McGill Questionnaire was used for evaluation of aspects that qualify and describe chronic pain (PIMENTA; TEIXEIRO, 1996). This instrument consists of 78 descriptors (words that qualify pain), organized into four categories (sensory, affective, evaluative and miscellaneous) and 20 subcategories (MARTINEZ; GRASSI; MARQUES, 2011; PIMENTA; TEIXEIRO, 1996). 
For evaluation of pain intensity, the patient should report the intensity of pain in a numerical scale varying from 0 to 10 , where 0 corresponds to the classification "No Pain" and 10 corresponds to the classification "Maximum Pain" (LEANDRO et al., 2014; MARTINEZ; GRASSI; MARQUES, 2011).

\section{Statistical analyses}

Data were entered into an electronic spreadsheet in the Excel® software for Windows $X P ®$, validated by double entry and exported to the Statistical Package for the Social Sciences (SPSS) version 20.0 for processing and analysis. Descriptive statistical analyses included absolute frequency, percentage, and measures of centrality (mean) and dispersion (maximum and minimum).

\section{RESULTS}

\section{Sociodemographic characteristics and health}

The study included 100 elderly aged 60 and 94 years (mean 71.1 years SD + 7.4). Most elderly were female, had incomplete primary education, were married, of the Catholic religion and were admitted to the Medical Clinic Unit (Table 1). As for health conditions, the most reported morbidity was Systemic Arterial Hypertension (SAH) (65\%) (Table 1). Among the health changes listed by the elderly, $57 \%$ had changes in the circulatory system, followed by changes in the digestive (17\%), endocrine $(16 \%)$, excretory $(15 \%)$, respiratory $(10 \%)$, skeletal $(8 \%)$, nervous $(5 \%)$, reproductive $(3 \%)$ and lymphatic (1\%) systems.

Table 1. Sociodemographic and health characteristics of hospitalized elderly patients. Minas Gerais (Brazil).

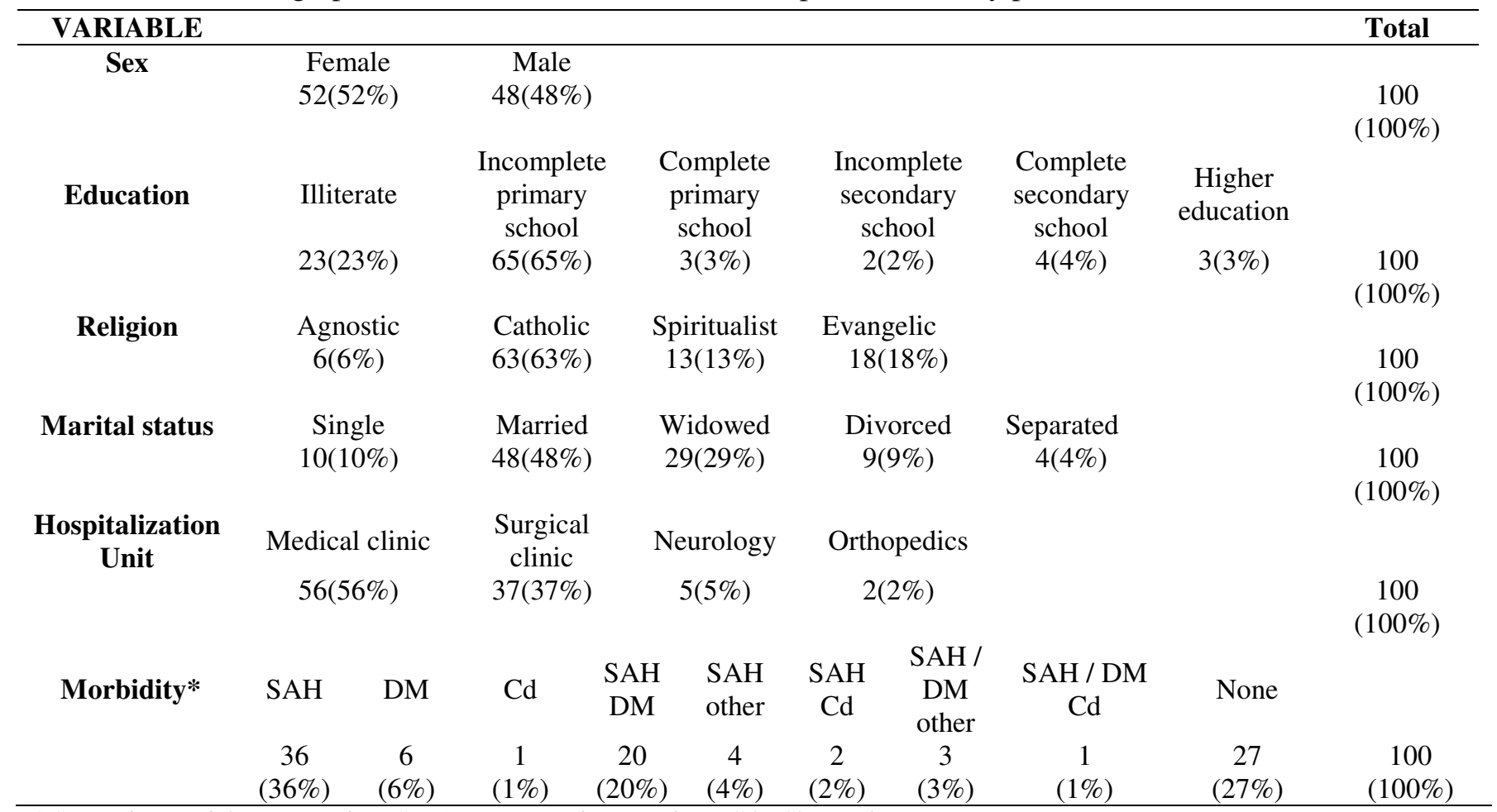

* Systemic Arterial Hypertension (SAH); DM = Diabetes Melitus; $\mathrm{Cd}=$ Chagas desease.

\section{Evaluation of chronic pain in hospitalized elderly}

As regards semiologic characteristics of chronic pain, a highest percentage of elderly patients reported musculoskeletal pain in the chest and musculoskeletal pain in the upper and lower limbs. Elderly patients with chronic pain of severe intensity prevailed in the sample, pointing to higher factor improves the use of drugs. Regarding the worsening factors, although most participants reported no presence of worsening factors, making effort and movement stood out (Table 2).
With regard to aspects relating to the Mc Gill pain questionnaire (Box 1), there was a predominance of tender and jumping classification in the sensitive category. In the affective category, suffocating and tiring feelings were the most frequently reported. In the evaluative category, the pain was unbearable and presented as intense. In the miscellaneous category, pain was characterized as nauseating, spreading and tight. 
Table 2. Characterization of the intensity, location, and improvement and worsening factors of chronic pain in hospitalized elderly. Minas Gerais (Brazil).

\begin{tabular}{lclclc}
\hline \multicolumn{1}{c}{ Intensity } & $\mathbf{n}$ & \multicolumn{1}{c}{ Improvement factors } & $\mathbf{n}$ & \multicolumn{1}{c}{ Worsening factor } & n \\
\hline Light & $\mathbf{2}$ & Use of medicines & $\mathbf{5 0}$ & None & $\mathbf{2 8}$ \\
Moderate & $\mathbf{2 0}$ & None & $\mathbf{1 4}$ & Effort & $\mathbf{1 4}$ \\
Severe & $\mathbf{7 8}$ & Rest & $\mathbf{1 2}$ & Movement & $\mathbf{1 3}$ \\
& & $\mathbf{9}$ & Food & $\mathbf{1 2}$ \\
& Others & $\mathbf{7}$ & Others & $\mathbf{1 1}$ \\
& Use of medicines / Rest & $\mathbf{3}$ & Laying down & $\mathbf{6}$ \\
& & Use of medicines /Tea & $\mathbf{2}$ & Sitting & $\mathbf{3}$ \\
& & Use of medicines /Others & $\mathbf{1}$ & Standing up & $\mathbf{3}$ \\
& Use of medicines /Massage & $\mathbf{1}$ & Effort/ Nervousness & $\mathbf{3}$ \\
& Tea/Massage & $\mathbf{1}$ & Effort/ Laying down & $\mathbf{2}$ \\
& Tea & $\mathbf{0}$ & Nervousness & $\mathbf{2}$ \\
& Massage & & Movement/others & $\mathbf{2}$ \\
\hline & & & Sitting/ standing up & $\mathbf{1}$ \\
\hline & & $\mathbf{1 0 0}$ & & $\mathbf{1 0 0}$ \\
\hline
\end{tabular}

Box 1. Evaluation of characteristics of sensory-affective-cognitive pain according the Mc Gill Pain Questionnaire, Minas Gerais (Brazil).

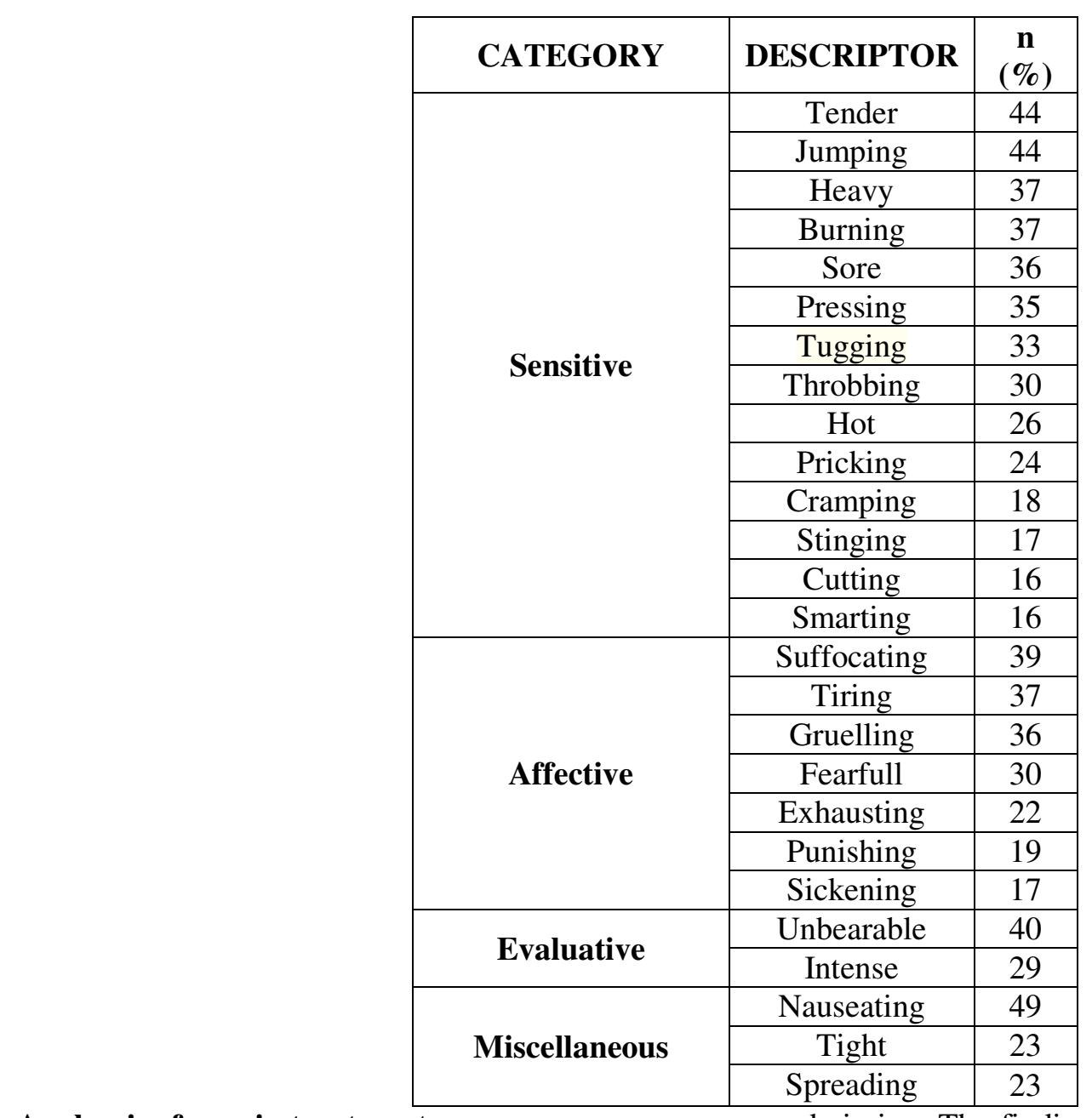

\section{Analgesics for pain treatment}

Regarding the use of analgesics, most elderly patients had been using simple analgesics for a year or more, and had used medicines before admission. The findings also indicated that most of the patients had used these drugs by prescription; in $33 \%$ of the medicines were of non-steroidal anti- 
inflammatory nature, and $31 \%$ were opioids (Table

$3)$.

Table 3. Characterization of the use of analgesics during hospitalization. Minas Gerais (Brazil).

\begin{tabular}{cccc}
\hline Use of analgesics & Yes & No & TOTAL \\
\hline $\begin{array}{c}\text { Before hospitalization } \\
\text { Prescribed analgesics }\end{array}$ & $68(68 \%)$ & $32(32 \%)$ & $100(100 \%)$ \\
$\begin{array}{c}\text { Simple analgesics at } \\
\text { home }\end{array}$ & $42(42 \%)$ & $4(4 \%)$ & $100(100 \%)$ \\
$\begin{array}{c}\text { Simple analgesics for a } \\
\text { year or more }\end{array}$ & $32(32 \%)$ & $58(58 \%)$ & $100(100 \%)$ \\
$\begin{array}{c}\text { Types of analgesics* } \\
\text { Simple analgesic } \\
\text { Non-steroidal anti- } \\
\text { inflammatory }\end{array}$ & $88(88 \%)$ & $68(68 \%)$ & $100(100 \%)$ \\
$\quad$ Opioids & $33(33 \%)$ & $12(12 \%)$ & $100(100 \%)$ \\
\hline
\end{tabular}

*analgesics used during hospitalization

\section{DISCUSSION}

The hospitalized elderly with a history of chronic pain in this study had a prevalence of females aged 70.9 years on average and had incomplete primary education. These results are in line with published data where chronic pain was more prevalent in female and older patients (MARTÍN-SÁNCHEZ et al., 2016; REID; ECCLESTON; PILEMER, 2015).

The low level of education found here corroborates other study conducted in Italy where the number of years of schooling was 6 to 7 full years on average (MARENGONI et al., 2015). In a previous investigation with hospitalized elderly people in the clinical and surgical wards in the same public teaching hospital where the present study was conducted, a higher prevalence of elderly people with 1 to 4 years of schooling was found (TARAVES et al., 2016). Therefore, the international guidelines for chronic pain management in the elderly has recommended increasing the level of information for the management of chronic pain in the elderly as an the important action (REID; ECCLESTON; PILEMER, 2015).
The predominance of Catholics in the population in this research reinforces the profile found in another study with elderly people in the community carried out in the same city $(69.5 \%)$ (RODRIGUES et al., 2017). In Brazil, the effect of religious practices in the prevention and cure of diseases is valued by the majority of the population (MELLO; OLIVEIRA, 2013), which is mostly made up of Catholics (64.6\%), as demonstrated in the last Brazilian IBGE census (IBGE, 2018).

The main observed morbidity was Systemic Arterial Hypertension (SAH), just as it has been found in studies conducted in France that analyzed pain and analgesia in the elderly in the postoperative period (DUALÉ et al., 2015). In Brazil, SAH is a major public health problem that is difficult to control, especially in the elderly population. According to the last census, SAH has a prevalence of more than $50 \%$ in elderly people in all regions of the country, including the southeast where the present study was conducted (MENDES; MORAIS; GOMES, 2014).

The prevalence of circulatory problems draws attention, since these have been source of a concern worldwide. Researches in the United States (HERON, 2015) and Austrália (O'CONNELL et al., 2014) highlight heart disease as the leading cause of 
death in the elderly. In Brazil, diseases of the circulatory system have called attention due to epidemiological changes in recent decades. Evidence of these data was obtained from the Hospital Information System of the Unified Health System (HIS/SUS), demographic data from the 2000 and 2010 censuses, and it was consolidated in DATASUS (MARQUES; CONFORTIN, 2015).

As for the site and intensity of pain, musculoskeletal pain in the chest region and musculoskeletal pain in the lower and upper limbs and severe intensity were the most mentioned answers. Musculoskeletal pain occurs more frequently with advancing age and the more common types are painful neuropathies of diabetes, herpes zoster, chemotherapy and surgery (REID; ECCLESTON; PILEMER, 2015). In a research about the costs of healthcare for elderly patients in France, chronic pain of moderate intensity prevailed among respondents (73\%) (LAZKANI et al., 2015). In turn, in a national study with adult and elderly patients admitted to a university hospital in the state of Paraíba, the majority reported intense pain (SOUSA-MUÑOZ et al., 2015).

The variation of pain intensity abovementioned highlights the need to take into account the subjectivity of this variable. Health professionals may underestimate pain in the elderly by associating it with the characteristics of the aging process. Therefore, the assessment of pain intensity and other semiological characteristics can contribute to guide the care, which may promote relief and comfort for the elderly in relation to the problem they are experiencing. It should be considered that chronic pain is a complex and multidimensional phenomenon that requires interdisciplinary actions for its control (BARBOSA et al., 2014).

The findings related to pain improvement factors showed the use of medicines was the main factor employed to improve pain relief, and physical stress was the main worsening factor. Research has shown that characteristics of the emotional state such as aggression and restlessness may be related to painful experiences and reflected in strategies to overcome this symptom (OLIVEIRA et al., 2013).

Regarding the improvement factors, the results found are similar to those reported in a survey of hospitalized adults and elderly patients (mean age $69.3 \pm 14.2$ years) in Portugal, where a large proportion of patients took drugs at home for pain, most frequently paracetamol (47.1\%) (SILVA; DIXE, 2013). A major concern today has been the facilitated availability of drugs in the pharmaceutical and supermarket sectors that can lead to the indiscriminate use of painkillers. This use happens even without previous evaluation and prescription or concomitant to alternative therapies for pain relief.

Although in the present research $96 \%$ of the elderly reported the use of prescribed painkillers, the use of analgesics should be better guided and monitored, because this research also showed that the use of painkillers, even the simplest kinds, is still high in the elderly population. It is important to consider the use of old prescribed drugs which are often stored by the elderly (REID; ECCLESTON; PILEMER, 2015). This fact calls for a reflection on the need to control the treatment of pain and use of analgesics for relief.

A cohort study that aimed to investigate the prolonged use of analgesics presented a positive association between the use of painkillers for long periods and osteoarthritis of the knee (HAFEZINEJAD et al., 2015). Despite the fact that evidence on the use patterns of non-steroidal analgesics in elderly people is scarce, $33 \%$ of the elderly in this study used non-steroidal anti-inflammatory analgesics and $31 \%$ used opioids. This fact draws attention to the results of a study conducted in Sydney, Australia, which showed that the practice of prescribing such painkillers does not align with clinical guidelines for safe use in the elderly. This difference between recommendations and actual use of these drugs should be further explored, since, as highlighted in the abovementioned research, users who make regular use of steroids were significantly more likely to report chronic pain than non-regular users (GNJIDIC et al., 2014).

A study carried out with elderly patients for pharmacotherapeutic follow-up of patients using opioids in a teaching hospital found that there was no record of pain measurement in $15.9 \%$ of the pharmaceutical evolutions (RIBEIRO; COSTA, 2015). This fact indicates, according to the authors, the importance of systematizing this evaluation in institutions.

It is noteworthy that opioids can cause a variety of adverse effects that may be aggravated in frail elderly patients. Based on this, in a study with hospitalized elderly in Italy, 58\% of patients with pain at discharge had not received prescribed analgesics (MARENGONI et al., 2014). The low prescription of opioids, according to the authors, occurred due to concern and caution on the part of physicians. Unlike the present study, $31 \%$ of the elderly used prescribed opioids during hospitalization. This fact is a cause of concern because these elderly people may present complications resulting from this use when they go home after discharge. This demonstrates that the 
need for prescriptions of opioids in hospitalized elderly in Brazil needs to be also in line with the specific clinical guidelines of this population.

It is emphasized that this study has as limitation the fact that it was carried out in a single assessment, a characteristic of the cross-sectional design. However, there is a notable lack of research on chronic pain and analgesic use in hospitalized elderly. This fact underscores the importance of conducting research like the present one in order to better understand the intervening factors related to pain and analgesic use and expand the strategies of adequate care for these patients.

\section{CONCLUSION}

It was possible to demonstrate in the study that intense pain was common among the hospitalized elderly and use of simple analgesics was a major source of relief. Moreover, regarding the characteristics of the assessed pain, this was characterized as tender, jumping, suffocating, tiring, unbearable, intense, nauseating, spreading and tight. These findings point to the need for multidisciplinary intervention programs focusing on the evaluation and treatment of this symptom among hospitalized elderly in addition to the use of medications in order to ensure the quality of life of this population. Nurses are important professionals in this setting, advising on options of lifestyle changes for the elderly, as well as referencing different services and professionals. This research makes it possible to improve nursing care for patients experiencing pain, as well as the elaboration of protocols for its evaluation and management.

RESUMO: Avaliar a dor crônica e o uso de analgésicos em idosos internados em um hospital de ensino. Estudo transversal, observacional, não experimental com 100 idosos. Utilizou-se instrumentos de coleta de dados sociodemográficos e de saúde, avaliação da escala de Mc Gill e intensidade da dor. Resultados: observou-se média de idade 71,1 anos (DP+7,4) e prevalência do sexo feminino (52\%); $78 \%$ relataram dor grave e $68 \%$ relataram usar analgésicos. A dor foi caracterizada como sensível e em pontada (44\%), sufocante (39\%), insuportável (40\%) e nauseante (49\%). Os achados deste estudo apresentam um alto índice de relato da dor crônica, apontando para a necessidade de criação de programas multiprofissionais de intervenções com foco na avaliação e tratamento desse sintoma entre os idosos hospitalizados.

PALAVRAS-CHAVE: Idoso. Dor Crônica. Hospitalização. Envelhecimento. Qualidade de vida. Manejo da dor.

\section{REFERENCES}

ABDULLA, A.; ADAMS, N.; BONE, M.; ELLIOTT, A. M.; GAFFIN, J.; JONES, D.; KNAGGS, R.; MARTIN, D.; SAMPSON, L.; SCHOFIELD, P. A. T. Guidance on the management of pain in older people. Age Ageing, v. 42, Suppl 1, 2013. Disponível em: < https://www.ncbi.nlm.nih.gov/pubmed/23420266>. Acesso em: 09 apr. 2018.

BARBOSA, M.; BOLINA, A. F.; TAVARES, J. L.; CORDEIRO, A. L. P. C.; LUIZ, R. B.; OLIVEIRA, K. F. Sociodemographic and health factors associated with chronic pain in institutionalized elderly. Rev. LatinoAm. Enfermagem, v. 22, n. 6, p. 1009-16, 2014. Disponível em: < https://www.revistas.usp.br/rlae/article/viewFile/99984/98531>. Acesso em: 09 apr. 2018.

BHATTARAI, P.; HICKMAN, L.; PHILLIPS, J. L. Pain among hospitalized older people with heart failure and their preparation to manage this symptom on discharge: a descriptive- observational study. Contemp. Nurse, p. 1-12, 2016. Disponível em: <https://www.ncbi.nlm.nih.gov/pubmed/27052106>. Acesso em: 09 apr. 2018.

BODILSEN, A. C.; KLAUSEN, H. H.; PETERSEN, J.; BEYER, N.; ANDERSEN, O.; JØRGENSEN, L. M.; JUUL-LARSEN, H. G.; BANDHOLM, T. Prediction of mobility limitations after hospitalization in older medical patients by simple measures of physical performance obtained at admission to the emergency. PLoS ONE, v. 128, p. 1-19, 2016. Disponível em: <http://journals.plos.org/plosone/article?id=10.1371/journal.pone.0154350>. Acesso em: 09 apr. 2018. 
DELLAROZA, M. S. G.; PIMENTA, C. A. M. MATSUO, T. Chronic pain among elderly residents in São Paulo, Brazil: prevalence, characteristics, and association with functional capacity and mobility (SABE Study). Cad. Saúde Pública, v. 29, n. 2, p. 325-334, 2013. Disponível em: $<$ http://www.scielo.br/scielo.php?script=sci_arttext\&pid=S0102-311X2013000200019> Acesso em: 09 apr. 2018.

DUALÉ, C.; PEREIRA, B.; ABBAL, B.; JULIEN, H.; RAT, P.; SCHOEFFLER, P.; PICKERING, G. The Algoplus Score to assess acute postoperative pain in elderly patients - a pilot observational study. Pain Manag. Nurs., v. 16, n. 6, p. 890-899, 2015. Disponível em: <https://www.ncbi.nlm.nih.gov/m/pubmed/26697817/>. Acesso em: 09 apr. 2018.

EGGERMONT, L. H. P.; LEVEILLE, S. G.; SHI, L.; KIELY, D. K.; SHMERLING, R. H.; JONES, R. N.; GURALNIK, J. M.; BEAN, J. F. Pain characteristics associated with the onset of disability in older adults: the maintenance of balance, independent living, intellect, and zest in the elderly boston study. J. Am. Geriatr. Soc., v. 62, n. 6, p. 1007-1016, 2014. Disponível em: <https://www.ncbi.nlm.nih.gov/pubmed/24823985>. Acesso em: 09 apr. 2018.

GNJIDIC, D.; BLYTH, F. M.; LE COUTEUR, D. G.; CUMMING, R. G.; MCLACHLAN, A. J.;

HANDELSMAN, D. J.; SEIBEL, M.; WAITE, L.; NAGANATHAN, V. Nonsteroidal anti-inflammatory drugs (NSAIDs) in older people: prescribing patterns according to pain prevalence and adherence to clinical guidelines. Pain, v. 155, n. 9, p. 1814-1820, 2014. Disponível em: <https://www.ncbi.nlm.nih.gov/pubmed/24954164>. Acesso em: 09 apr. 2018.

HAFEZI-NEJAD, N.; GUERMAZI, A.; ROEMER, F. W.; ENG, J.; ZIKRIA, B.; DEMEHRI, S. Long term use of analgesics and risk of osteoarthritis progressions and knee replacement: propensity score matched cohort analysis of data from the Osteoarthritis Initiative. Osteoarthritis and Cartilage, v. 24, n. 4, p. 597-604, 2015. Disponível em: <https://www.ncbi.nlm.nih.gov/pubmed/26564576>. Acesso em: 09 apr. 2018.

HERON, M. Deaths: leading causes for 2011. National vital statistics reports : from the Centers for Disease Control and Prevention, National Center for Health Statistics,

Nat. Vital Stat. Rep., v. 64, p. 1-95, 2015. Disponível em: <https://www.ncbi.nlm.nih.gov/pubmed/26222685>. Acesso em: 09 apr. 2018.

HOFMAN, S. E.; LUCKE, J. A.; HEIM, N.; GELDER, J.; FOGTELOO, A. J.; HERINGHAUS, C.; GROOT, B.; CRAEN, A. J. M.; BLAUW, G. J.; MOOIJAART, S. P. Prediction of 90-day mortality in older patients after discharge from an emergency department : a retrospective follow-up study. BMC Emerg. Med., p. 1- 10, 2016. Disponível em: <https://www.ncbi.nlm.nih.gov/pmc/articles/PMC4944462/>. Acesso em: 09 apr. 2018.

IBGE [INSTITUTO BRASILEIRO DE GEOGRAFIA E ESTATÍSTICA]. Cidades. Disponível em: $<$ http://cidades.ibge.gov.br/>. Acesso em: 07 abril 2018.

LAZKANI, A.; DELESPIERRE, T.; BAUDUCEAU, B.; PASQUIER, F.; BERTIN, P.; BERRUT, G.; CORRUBLE, E.; DOUCET, J.; FALISSARD, B.; FORETTE, F.; HANON, O.; BENATTAR-ZIBI, L.; PIEDVACHE, C.; BECQUEMONT, L. Healthcare costs associated with elderly chronic pain patients in primary care. Eur. J. Clin. Pharmacol., v. 71, n. 8, p. 939-947, 2015. Disponível em: <https://www.ncbi.nlm.nih.gov/pubmed/26004570>. Acesso em: 09 apr. 2018.

LEANDRO, J. D.; RODRIGUES, O. R.; SLAETS, A. F. F.; SCHMIDT JR., A. F; YAEKASHI, M. L. Comparison between two thoracotomy closure techniques: postoperative pain and pulmonary function. J. Bras. Pneumol., v. 40, p. 389-396, 2014. Disponível em: <https://www.ncbi.nlm.nih.gov/pmc/articles/PMC4201169/> Acesso em: 09 apr. 2018.

MALEC, M.; SHEGA, J. W. Pain Management in the elderly. Med. Clin. North Am., v. 99, n. 2, p. 337-350, 2015. Disponível em: <https://www.ncbi.nlm.nih.gov/pubmed/25700587>. Acesso em: 09 apr. 2018. 
MARENGONI, A.; NOBILI, A.; CORLI, O.; DJIGNEFA, C. D.; BERTONI, D.; TETTAMANTI, M.; PASIN, L.; CORRAO, S.; SALERNO, F.; MARCUCCI, M.; MANNUCCI, P. M. The stigma of low opioid prescription in the hospitalized multimorbid elderly in Italy. Intern. Emerg. Med., v. 10, p. 305-313, 2015. Disponível em: <https://www.ncbi.nlm.nih.gov/pubmed/25248643>. Acesso em: 09 apr. 2018.

MARQUES, L.; CONFORTIN, S. Doenças do Aparelho Circulatório: Principal Causa de Internações de Idosos no Brasil entre 2003 e 2012. Revista Brasileira de Ciências da Saúde, v. 19, n. 2, p. 83-90, 2015. Disponível em: <http://www.periodicos.ufpb.br/index.php/rbcs/article/view/23631/15055>. Acesso em: 09 apr. 2018.

MARQUES, A. P.; MONTILLA, D. E. R.; ALMEIDA, W. S.; ANDRADE, C. L. T. Hospitalization of older adults due to ambulatory care sensitive conditions. Revista de Saúde Pública, v. 48, n. 5, p. 817-826, 2014. Disponível em: <https://www.ncbi.nlm.nih.gov/pubmed/25372173>. Acesso em: 09 apr. 2018.

MARTINEZ, J. E.; GRASSI, D. C.; MARQUES, L. G. Analysis of the applicability of different pain questionnaires in three hospital settings: outpatient clinic, ward and emergency unit. Rev. Bras. Reumatol., v. 51, n. 4, p. 299-308, 2011. Disponível em: <https://www.ncbi.nlm.nih.gov/pubmed/21779706>. Acesso em: 09 apr. 2018.

MARTÍN-SÁNCHEZ, F. J. JULIÁN-JIMÉNEZ, A.; GONZÁLEZ, F. J. C.; ROCA, F. L.; ZÁRATE, M. M. O.; CASTILLO, J. G. Perfil y manejo inicial de los ancianos atendidos por infección en los servicios de urgencias hospitalarios. Rev. Esp. Geriatr. Gerontol., v. 52, n. 1, p. 9-14, 2016. Disponível em: $<$ https://www.sciencedirect.com/science/article/pii/S0211139X16000573>. Acesso em: 09 apr. 2018.

MELLO, M. L.; OLIVEIRA, S. S. Health, religion and culture: a dialogue based on Afro-Brazilian customs. Saúde Soc., v. 22, n. 4, p. 1-12, 2013. Disponível em: <http://www.scielo.br/scielo.php?pid=S010412902013000400006\&script=sci_arttext\&tlng=en>. Acesso em: 09 apr. 2018.

MENDES, G. S.; MORAES, C. F.; GOMES, L. Prevalence of hypertension in elderly in Brazil between 2006 and 2010. Rev. Bras. Med. Fam. Comunidade. Rio de Janeiro, v. 9, n. 32, p. 273-278, 2014.

O'CONNELL, D. L.; GOLDSBURY, D. E.; DAVIDSON, P.; GIRGIS, A.; PHILLIPS, J. L.; PIZA, M.; WILKINSON, A.; INGHAM, J. M. Acute hospital-based services utilisation during the last year of life in New South Wales, Australia: methods for a population-based study. BMJ Open, v. 4, n. 3, p. e004455, 2014. Disponível em: <https://www.ncbi.nlm.nih.gov/pubmed/24682576>. Acesso em: 09 apr. 2018.

OLIVEIRA, C. M.; CARVALHO, D. V.; MATOS, S. S.; SOARES, S. M.; MALHEIROS, J. A.; ARANTES JÚNIOR, A. A. Pain in hospitalized elders with musculoskeletical dysfunction. Rev. Med. Minas Gerais, v. 23, n. 1, p. 33-38, 2013. https://doi.org/10.5935/2238-3182.20130006

PATEL, K. V.; PHELAN, E. A.; LEVILLE, S. G.; LAMB, S. E.; MISSIKPODE, C.; WALLACE, R. B.; GURALNIK, J. M.; TURJ, D. C. High prevalence of falls, fear of falling, and impaired balance in older adults with pain in the United States: Findings from the 2011 National Health and Aging Trends Study. J. Am. Geriatr. Soc., v. 62, n. 10, p. 1844-1852, 2014. Disponível em: <https://www.ncbi.nlm.nih.gov/pubmed/25283473>. Acesso em: 09 apr. 2018.

PIMENTA, C. A.; TEIXEIRO, M. J. Adaptation of McGill questionnaire to portuguese language. Rev. Escol. Enferm. USP, v. 30, n. 3, p. 473-483, 1996. Disponível em: $<\mathrm{http} / / /$ www.scielo.br/scielo.php?script=sci_abstract\&pid=S008062341996000300009\&lng=en\&nrm=iso\&tlng=en>. Acesso em: 09 apr. 2018.

REID, M. C.; ECCLESTON, C.; PILLEMER, K. Management of chronic pain in older adults. BMJ Journal. v. 350, p. h532, 2015. Disponível em: <https://www.ncbi.nlm.nih.gov/pmc/articles/PMC4707527/>. Acesso em: 09 apr. 2018. 
RIBEIRO, H. S. S.; COSTA, J. M. Drug therapy monitoring of elderly patients in a teaching hospital. Rev. Bras. Farm. Hosp. Serv. Saúde São Paulo, v.6, n.1, p. 18-23, 2015. Disponível em:

<http://www.sbrafh.org.br/rbfhss/public/artigos/2015060104000654BR.pdf>. Acesso em: 09 apr. 2018.

RODRIGUES, L. R.; NADER, I. D.; MELO E SILVA, A. T.; TAVARES, D. M. S.; ASSUNÇÃO, L. M.; MOLINA, N. P. F. M. Spirituality and religiosity related to socio-demographic data of the elderly population. Rev. Rene, v. 18, n. 4, p. 429-436, 2017. Disponível em:

<http://www.revistarene.ufc.br/revista/index.php/revista/article/view/2699>. Acesso em: 09 apr. 2018.

SILVA, E. J. G. D. G.; DIXE, M. A. C. R. Pain prevalence and characteristics in patients admitted to a Portuguese hospital. Rev. Dor (São Paulo), v. 14, n. 4, p. 245-250, 2013. Disponível em: $<$ http://www.scielo.br/scielo.php?script=sci_arttext\&pid=S1806-00132013000400003 >. Acesso em: 09 apr. 2018.

SOUSA-MUÑOZ, R. L.; ROCHA, G. E. S.; GARCIA, B. B.; MAIA, A. D. Prevalence of Pain and analgesic therapy adequacy in patients hospitalized in a university hospital. Medicina (Ribeirão Preto), v. 48, n. 6, p. 539-548, 2015. Disponível em:

<https://www.journals.usp.br/rmrp/user/setLocale/es_ES?source=\%2Frmrp\%2Farticle\%2Fview\%2F114913>. Acesso em: 09 apr. 2018.

TAVARES, D. M. S.; COLAMEGO, C. G.; PEGORARI, M. S.; FERREIRA, P. C. S.; DIAS, F. A.; BOLINA, A. F. Cardiovascular risk factors associated with frailty syndrome among hospitalized elderly people: a crosssectional study. São Paulo Med. J., v. 134, n. 5, p. 393-399, 2016. Disponível em:

<http://www.scielo.br/scielo.php?script=sci_arttext\&pid=S1516-31802016000500393 >. Acesso em: 09 apr. 2018. 